\title{
A COUPLE OF COLLECTIVE UTILITY AND MINIMUM PAYOFF PARITY LOSS RULES FOR REFINING NASH EQUILIBRIA IN BIMATRIX GAMES WITH ASYMMETRIC PAYOFFS
}

\section{V. Romanuke}

Polish Naval Academy

69 Śmidowicza Street, Gdynia, Poland, 81-127. E-mail: romanukevadimv@gmail.com

Purpose. For furthering the known approaches to the Nash equilibria refinement, an approach should be suggested that could exploit more than just one technique of operating over payoffs in bimatrix games. The payoffs must be asymmetric as refining Nash equilibria with symmetric payoffs without additional information is impossible. For creating the new approach, initial denotations, a convention on payoff matrices, a convention on the players' rationalism, and a refinement mathematical problem are to be stated. Methodology. Values of entries in payoff matrices have identical measurement units. Without loss of generality, we also presume the payoff matrices to be nonnegative. A number of efficient Nash equilibria is presumed to be greater than 1. At least a pair of players' payoffs in an efficient Nash equilibrium must have diverse payoffs. At least a pair of players' payoffs in an efficient Nash equilibrium must be different from other pairs/pair. The players are assumed to be not ultimately avaricious implying that some concessions/retreats are admissible. Players may lose more without retreats but the retreat must be made by a single player. A minimal retreat must be chosen. An efficient Nash equilibrium corresponding to the minimal retreat is then focused on and called a metaequilibrium. Findings. A two-criteria problem for the metaequilibrium is stated, wherein the collective utility is maximized and the payoff parity loss is minimized. This problem is solved via scalarization with weighing the criteria. Originality. A couple of collective utility and minimum payoff parity loss rules is used as for refining Nash equilibria, as well as for ranking efficient Nash equilibria. Practical value. The metaequilibrium prevents the players from springing off equilibria themselves. Its applications are basically in law, economics, bioecological processes, where interaction events need the equilibria. References 18, figures 4.

Key words: Nash equilibria, refinement, bimatrix games, collective utility, payoff parity loss, metaequilibrium.

\section{ПАРА ПРАВИЛ КОЛЕКТИВНОЇ КОРИСНОСТІ І МІНІМАЛЬНИХ ВТРАТ ПАРИТЕТУ ВИГРАШІВ ДЛЯ ВІДБОРУ РІВНОВАГ НЕША У БІМАТРИЧНИХ ІГРАХ 3 АСИМЕТРИЧНИМИ ВИГРАШАМИ \\ В. В. Романюк}

Військово-морська Академія Польщі

вул. Шмидовича, 69, м. Гдиня, Польща, 81-127. E-mail: romanukevadimv@ gmail.com

Для вдосконалення відомих підходів до відбору рівноваг Неша має бути запропонуваний підхід, який би міг використати більше, ніж просто одну методику оперування над виграшами в біматричних іграх. Виграші повинні бути асиметричними, оскільки відбір рівноваг Неша з симетричними виграшами без додаткової інформації неможливий. Для створення такого нового підходу мають бути сформульовані початкові позначення, конвенція щодо матриць виграшів, конвенція про раціоналізм гравців та математична задача відбору. Значення елементів матриць виграшів мають однакові одиниці вимірювання. Без втрати загальності ми також припускаємо, що матриці виграшів є невід'ємними. Припускається, що кількість ефективних рівноваг Неша перевищує 1. Принаймні одна пара виграшів гравців у ефективній рівновазі Неша повинна мати різні виграшів. Принаймні одна пара виграшів гравців у ефективній рівновазі Неша повинна відрізнятися від інших пар/пари. Припускається, що гравці не є суто жадібними, тобто деякі поступки/відступи є допустимими. Гравці можуть втратити без відступів більше, але відступ повинен бути здійснений одним гравцем. Необхідно вибрати мінімальний відступ. Відтак відбувається фокусування на ефективну рівновагу Неша, яка відповідає мінімальному відступу і називається метарівновагою. Викладено двокритеріальну задачу для метарівноваги, в якій колективна корисність максимізується, а втрата паритету виграшів - мінімізується. Ця задача вирішується шляхом скаляризації зі зважуванням критеріїв. Пара правил колективної корисності та мінімальних втрат паритету виграшів використовується як для відбору рівноваг Неша, так і для ранжування ефективних рівноваг Неша. Метарівновага не дозволяє гравцям зістрибувати з самих рівноваг. Її застосування в основному стосується права, економіки, біоекологічних процесів, де явища взаємодії потребують тих рівноваг.

Ключові слова: рівноваги Неша, відбір, біматричні ігри, колективна корисність, втрата паритету виграшів, метарівновага.

PROBLEM STATEMENT. Importance of refining Nash equilibria. Noncooperative games (NCGs) fit to model interactions amongst subjects having dissimilar goals and awards for realization of their strategies. Traditionally, those subjects are called players assumed to be rational in making choices of their strategies. Rationality is a primary assumption of game theory, which is a normative theory as it just pinpoints decisions that players should choose [1, 2]. For a lot of game models, these decisions constitute Nash equilibria (NEa). Often the NCG suggests for the player more than one NE strategy.
Thus NEa must be refined for obtaining a single equilibrium, otherwise an uncertainty, for removing which the game is intended, will stay and thus the game solution will have no reason $[3,4]$.

Known approaches to refining NEa. Every known approach to refine NEa exploits only some single technique, which aims at receiving greater payoffs or lesser losses. This may concern as individual payoffs/losses (or, in general, utility), as well as group or coalition utility $[5,6]$. It is impossible to get always a perfect refinement in such a way. Neither concepts of strong 
NE [5, 6], Mertens-stable equilibrium [7], trembling hand perfect equilibrium [8], proper equilibrium [9, 10], nor concepts of sequential $[11,12]$ and quasi-perfect equilibria [10, 13, 14] guarantee a single refined $\mathrm{NE}$ (SRNE) even in finite NCGs or, moreover, in bimatrix games (BMGs). Here, refinement falls on only pure strategy NEa because mixed strategy approaches require that the game be repeatable $[15,16]$. Repeatable NCGs are really very rare due to payoffs cannot be still stable for a long period of time, even if the game repeatability happens.

The paper goal and tasks. For furthering the known approaches to the NEa refinement, an approach should be suggested that could exploit more than just one technique of operating over payoffs in BMGs. Surely, the payoffs must be asymmetric as refining NEa with payoffs $\{\beta, \gamma\}$ and $\{\gamma, \beta\}$ without additional information is impossible. For creating the new approach, initial denotations, a convention on payoff matrices (PMs), a convention on the players' rationalism, and a refinement mathematical problem are to be stated.

MATERIAL AND RESEARCH RESULTS. Initial denotations. Consider a BMG with PMs

$$
\mathbf{A}=\left(a_{k j}\right)_{M \times N} \text { and } \mathbf{B}=\left(b_{k j}\right)_{M \times N}
$$

of the first and second players, whose sets of pure strategies are $X=\left\{x_{k}\right\}_{k=1}^{M}$ and $Y=\left\{y_{j}\right\}_{j=1}^{N}$, where $M \in \mathbb{N} \backslash\{1\}$, $N \in \mathbb{N} \backslash\{1\}$, respectively. Let values of entries in PMs (1) have identical measurement units. Without loss of generality, we also presume PMs (1) to be nonnegative. Negative payoffs are surely possible in some NCGs, but PMs can always be made nonnegative by adding some positive number to them (zeros may be left for convenience in calculations). That will not change $\mathrm{NEa}$, and true payoffs are returned by subtracting the added positive number $[1,2]$.

Let $E=\left\{z_{q}\right\}_{q=1}^{Q}$ be a set of efficient NEa (ENEa), where $1<Q<M \cdot N$ and

$$
z_{q}=\left\{x_{q}^{*}, y_{q}^{*}\right\} \text { by } x_{q}^{*} \in X \text { and } y_{q}^{*} \in Y \text {. }
$$

At ENE (2) players get payoffs $\left\{a_{k_{*}^{(q)} j_{*}^{(q)}}, b_{k_{*}^{(q)} j_{*}^{(q)}}\right\}$. This implies that neither a couple of inequalities

$$
a_{k_{*}^{(q)} j_{*}^{(q)}} \leqslant a_{k_{*}^{(s)} j_{*}^{(s)}} \text { and } b_{k_{*}^{(q)} j_{*}^{(q)}}<b_{k_{*}^{(s)} j_{*}^{(s)}}
$$

nor a couple of inequalities

$$
a_{k_{*}^{(q)} j_{*}^{(q)}}<a_{k_{*}^{(s)} j_{*}^{(s)}} \text { and } b_{k_{*}^{(q)} j_{*}^{(q)}} \leqslant b_{k_{*}^{(s)} j_{*}^{(s)}}
$$

is possible for any $s \in\{\overline{1, Q}\}$ by $k_{*}^{(q)} \in\{\overline{1, M}\}, j_{*}^{(q)} \in\{\overline{1, N}\}$.

Convention on payoff asymmetry and diversity. As it has been mentioned above, payoffs

$$
\left\{a_{k_{*}^{(q) j_{*}^{(q)}}}, b_{k_{*}^{(q)} j_{*}^{(q)}}\right\}_{q=1}^{Q}
$$

must be asymmetric. Formally, if

$$
\left\{a_{k_{*}^{(r)} j_{*}^{(r)}}, b_{k_{*}^{(r)} j_{*}^{(r)}}\right\}=\{\beta, \gamma\} \quad \forall r \in R \subset\{\overline{1, Q}\} \quad \text { by } R \neq \varnothing
$$

and

$$
\left\{a_{k_{*}^{(t)} j_{*}^{(t)}}, b_{k_{*}^{(t)} j_{*}^{(t)}}\right\}=\{\gamma, \beta\} \quad \forall t \in T=\{\{\overline{1, Q}\} \backslash R\} \quad \text { by } T \neq \varnothing
$$

then such payoffs are symmetric, and refining those ENEa will not be considered here. Besides, at least a pair of players' payoffs in an ENE must have diverse payoffs, i. e. a case

$$
a_{k_{*}^{(q)} j_{*}^{(q)}}=\beta \quad \text { and } b_{k_{*}^{(q)} j_{*}^{(q)}}=\beta \quad \forall q=\overline{1, Q}
$$

will not be considered here. Another diversity concerns the payoff pairs: at least a pair of players' payoffs in an ENE must be different from other pairs/pair, i. e. a case

$$
a_{k_{*}^{(q)} j_{*}^{(q)}}=\beta \quad \text { and } b_{k_{*}^{(q)} j_{*}^{(q)}}=\gamma \quad \forall q=\overline{1, Q}
$$

will not be considered here. Factually, the diversity in payoff pairs includes the diversity in payoffs.

Default collaboration. The rational players are assumed to be not ultimately avaricious. This implies that some concessions are admissible (e. g., see [15]) in cases when $E=\varnothing$ or $|E|>1$. It relies on some retreat from eager individuality as in those cases it either gives nothing or does not stop the game (a few ENEa generate a new BMG). Clearly, the retreat is measured in the payoff that is lost. Let this principle be called a default collaboration, which is turned on for the cases when $|E|>1$ and a refinement is required. By the default collaboration, the player tends to improve also the collective utility possible by one's losing a little. This does not contradict the principle of NCGs "not to cooperate" because without the retreat the player may lose more.

As an example, consider a $2 \times 2$ BMG with PMs

$$
\mathbf{A}=\left(\begin{array}{ll}
2 & 4 \\
3 & 2
\end{array}\right) \text { and } \mathbf{B}=\left(\begin{array}{ll}
1 & 4 \\
5 & 0
\end{array}\right) \text {. }
$$

In BMG with PMs (5) we have two ENEa: they are situations $z_{1}=\left\{x_{1}, y_{2}\right\}$ and $z_{2}=\left\{x_{2}, y_{1}\right\}$ with the respective payoffs $\{4,4\}$ and $\{3,5\}$. At first glance, the first player here should tend to use just $x_{1}$ hoping for payoff $a_{12}=4$ rather than payoff $a_{21}=3$. In the same time, the second player would use $y_{1}$ hoping for payoff $b_{21}=5$ rather than payoff $b_{12}=4$. If it was so, the players' actions would make situation $\left\{x_{1}, y_{1}\right\}$ in which their payoffs are just $\{2,1\}$. Therefore, eager individual reasoning is just non-profitable here.

In a generalization case of $2 \times 2$ BMGs whose PMs

$$
\mathbf{A}=\left(\begin{array}{cc}
a_{11} & \alpha \\
\alpha-\delta & a_{22}
\end{array}\right) \text { and } \mathbf{B}=\left(\begin{array}{cc}
b_{11} & \alpha \\
\alpha+\delta & b_{22}
\end{array}\right)
$$

by

$$
\alpha-\delta>\max \left\{a_{11}, a_{22}, b_{11}, b_{22}\right\} \text { and } \alpha>0, \delta>0,
$$

the same eager individual reasoning is non-profitable for both players. If $\alpha$ and $\delta$ are much greater than diagonal entries of PMs (6), then the corresponding negative result becomes dramatic. It is so if even just $\alpha$ itself is much greater than those diagonal entries. A local example to the said is, say, a BMG with PMs

$$
\mathbf{A}=\left(\begin{array}{cc}
a_{11} & 10 a_{11} \\
7 a_{11} & a_{11}
\end{array}\right) \text { and } \mathbf{B}=\left(\begin{array}{cc}
b_{11} & 10 a_{11} \\
13 a_{11} & b_{22}
\end{array}\right),
$$

where the first player, if without the default collaboration, loses six parts of one's payoff in the worse ENE. The second players loses at least $10 a_{11}-b_{11}$.

The default collaboration must primarily help players not to spring off ENEa. Besides, it particularly must help in selecting amongst ENEa. In simple words, the player should be aware of the plain disequilibrium of ENEa. As a consequence, an equilibrium within ENEa is to be found. Finding such an equilibrium is only possible with a retreat made by one of the players. The re- 
treat must be made by a single player. Otherwise, if they both retreat, ENEa will be lost (the players will spring off ENEa).

What is the core of the default collaboration? For not violating the principle of NCGs "not to cooperate", probable retreats of the players are compared. Each player compares one's retreat/retreats to retreat/retreats of the other players. Eventually, a minimal retreat must be chosen. An ENE corresponding to the minimal retreat is then focused on. This ENE might be called a metaequilibrium.

Why should that metaequilibrium be as it has been said? Because we know that the equilibrium is that what is attractive to players. The player cannot improve one's payoff or just lose some part of one's equilibrium payoff if leaving the equilibrium. The same thing with the metaequilibrium. Retreats are unavoidable, so if a player who made one's retreat springs off a metaequilibrium implying a minimal retreat, then this player will lose just more. The other player who made no retreat does not have a reason to spring off the metaequilibrium.

An obvious example of the said metaequilibrium is in BMG with PMs (5). The collective utility here (the sum of payoffs in an ENE) is identical being equal to 8 . For now, we do not know yet how to find a metaequilibrium. But assume that situation $\left\{x_{1}, y_{2}\right\}$ is the metaequilibrium (by some reasoning). In this situation, the second player retreats decreasing one's payoff from 5 to 4 . Springing off strategy $y_{2}$ to strategy $y_{1}$ makes no sense. The first player will surely hold at strategy $x_{1}$ and the same payoff (which is maximal for the first player). If situation $\left\{x_{2}, y_{1}\right\}$ is the metaequilibrium, then the first player retreats decreasing one's payoff from 4 to 3. Springing off strategy $x_{2}$ to strategy $x_{1}$ makes no sense. The second player will surely hold at strategy $y_{1}$ and the maximal one's payoff.

A two-criteria problem for the metaequilibrium. For finding the metaequilibrium, the collective utility must be maximized. On the other hand, difference between players' payoffs in the metaequilibrium should not be much great. Therefore, it would be good to maximize players' collective payoffs and minimize their difference (a loss of payoff parity) simultaneously:

$$
\max _{q=1, Q}\left(a_{k_{*}^{(q)} j_{*}^{(q)}}+b_{k_{*}^{(q)} j_{*}^{(q)}}\right) \text { and } \min _{q=1, Q}\left|a_{k_{*}^{(q)} j_{*}^{(q)}}-b_{k_{*}^{(q)} j_{*}^{(q)}}\right| \text {. }
$$

Problems (8) are formulated practically as to find the corresponding indices at which extrema (8) are reached:

$$
\begin{gathered}
q_{\text {util }} \in \underset{q=1, Q}{\arg \max }\left(a_{k_{*}^{(q)} j_{*}^{(q)}}+b_{k_{*}^{(q)} j_{*}^{(q)}}\right)=\arg \underset{q=1, Q}{\max } u(q), \\
q_{\text {loss }} \in \underset{q=1, Q}{\arg \min }\left|a_{k_{*}^{(q)} j_{*}^{(q)}}-b_{k_{*}^{(q) j_{*}^{(q)}}}\right|=\arg \underset{q=1, Q}{\min } l(q) .
\end{gathered}
$$

Collective utility function $u(q)$ in (9) is always positive, and payoff parity loss function $l(q)$ in (10) is nonnegative. Indeed, the case $u(q)=0$ is impossible due to our convention on the nonnegative PMs and the diversity in payoffs. The same convention is followed by that at least one ENE exists with different payoffs.

Tasks (8) or (9) and (10) factually constitute a twocriteria problem whose solutions are generally different: $q_{\text {util }} \neq q_{\text {loss }}$. This is not acceptable as we obviously need always that they be identical: $q_{\text {util }}=q_{\text {loss }}$.
Scalarization. For solving two-criteria problem (9) and (10), a scalarization can be invoked. Before unifying problems (9) and (10) into one (single-criterion) problem, a normalization is required. Note that the collective utility function $u(q)$ and payoff parity loss function $l(q)$ cannot be normalized independently [17]. The losses are less than the payoff sums, so we normalize them to the grand total of all the payoff sums:

$$
\tilde{u}(q)=u(q) / \sum_{s=1}^{Q} u(s) \text { and } \tilde{l}(q)=l(q) / \sum_{s=1}^{Q} u(s) .
$$

The normalization allows having the following properties:

$$
\begin{gathered}
0<\tilde{u}(q)<1 \text { and } 0 \leqslant \tilde{l}(q)<\tilde{u}(q)<1 \quad \forall q=\overline{1, Q} \\
\text { but } \exists q_{0} \in\{\overline{1, Q}\} \text { such that } \tilde{l}\left(q_{0}\right)>0 .
\end{gathered}
$$

Then each point $\{\tilde{u}(q), \tilde{l}(q)\}$ can be considered on the half-open square on a plane whose point $\{1,0\}$ is the unreachable maximum of the normalized payoffs and minimum of the normalized parity losses. The usual distance between points $\{\tilde{u}(q), \tilde{l}(q)\}$ and $\{1,0\}$ is (e. g., see Figure 1)

$$
\sqrt{(1-\tilde{u}(q))^{2}+\tilde{l}^{2}(q)} \text { by } q=\overline{1, Q}
$$

that is a direct way of scalarizing two-criteria problem (9) and (10). Therefore, the two-criteria problem is solved as

$$
q_{*} \in \arg \min _{q=1, Q} \sqrt{(1-\tilde{u}(q))^{2}+\tilde{l}^{2}(q)} .
$$

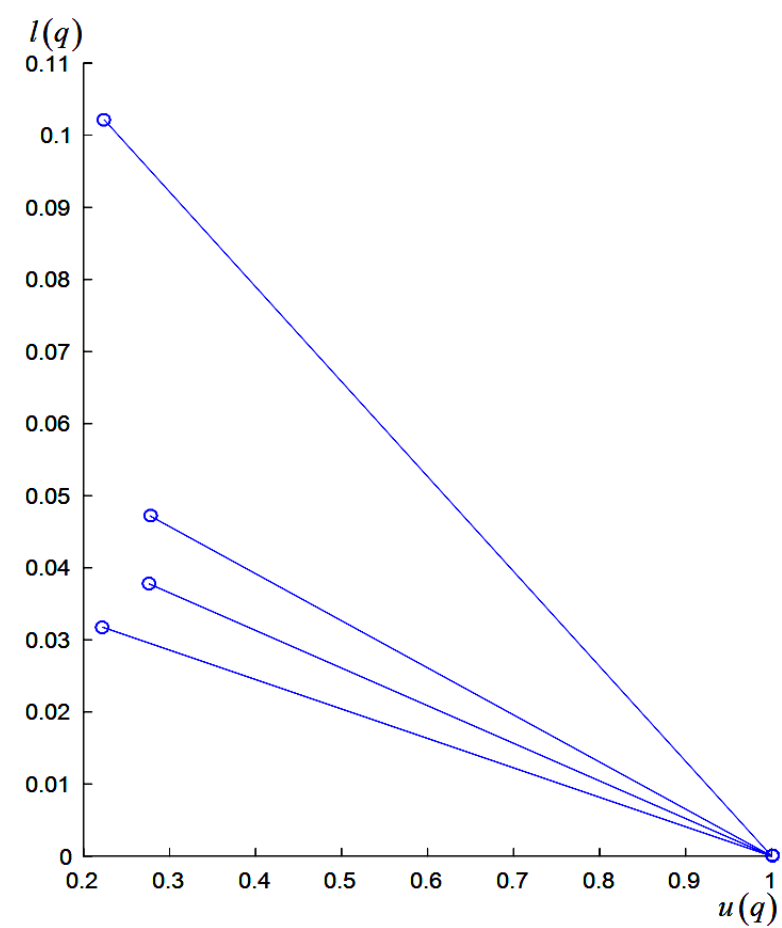

Figure 1 - Distances (13) shown as line segments between points $\{\tilde{u}(q), \tilde{l}(q)\}$ and $\{1,0\}$ for a $7 \times 6 \mathrm{BMG}$ with 4 ENEa (the shortest distance is not seen clearly, and it is roughly $8 \%$ shorter than the longest one)

A case of weighing the criteria. Distance (13) considers components $u(q)$ and $l(q)$ as equally weighted. But sometimes collective utility is nonetheless more important than losses in payoff parity. The opposite case 
is not excluded as well. For supporting those possibilities, let $\mu$ be a weight of the collective utility function, where $\mu \in(0 ; 1)$. Then a weighted distance

$$
\sqrt{(1-\mu \tilde{u}(q))^{2}+(1-\mu)^{2} \tilde{l}^{2}(q)} \text { by } q=\overline{1, Q}
$$

between points $\{\tilde{u}(q), \tilde{l}(q)\}$ and $\{1,0\}$ might have been used instead of distance (13) allowing two-criteria problem (9) and (10) to be solved as

$$
q_{*} \in \arg \min _{q=1, Q} \sqrt{(1-\mu \tilde{u}(q))^{2}+(1-\mu)^{2} \tilde{l}^{2}(q)}
$$

instead of (14). However, it is easy to see (e. g., in Figure 2 but keep in mind that the lines are as zoomed as those ones in Figure 1 because the ordinate axis have been stretched) that setting $\mu=0.5$ makes no linear proportion between distances (13) and (15). Thus, problem (16) by $\mu=0.5$ is not equivalent to problem (14) scaling the axes in that manner scales distances nonlinearly. This is pretty inconvenient in practice [17].

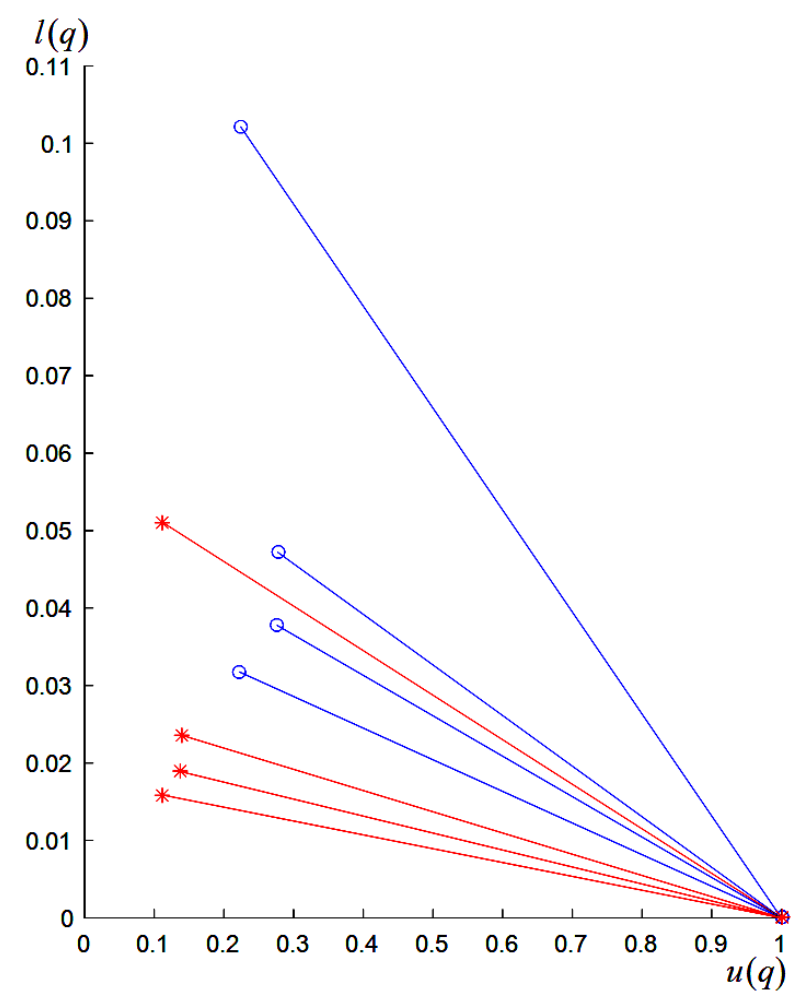

Figure 2 - The example of the $7 \times 6 \mathrm{BMG}$ with those 4 ENEa mentioned in Figure 1, where setting $\mu=0.5$ for weighted distance (15) distorts the proportions between those 4 distances (the starred dots) as now the shortest distance is only $3.2 \%$ shorter than the longest one

Hence, the weight of the collective utility function should be applied in another way - to its squared distance to the unreachable maximum of the normalized payoffs. Then distance

$$
d(q, \mu)=\sqrt{\mu(1-\tilde{u}(q))^{2}+(1-\mu) \tilde{l}^{2}(q)} \text { by } q=\overline{1, Q}
$$

and problem

$$
\begin{gathered}
q_{*} \in \arg \min _{q=1, Q} \sqrt{\mu(1-\tilde{u}(q))^{2}+(1-\mu) \tilde{l}^{2}(q)}= \\
=\arg \min _{q=1, Q} d(q, \mu)
\end{gathered}
$$

are the general case of weighing the criteria. Now problem (18) by $\mu=0.5$ is equivalent to problem (14).

Setting weight $\mu$ is a special task. If the collective utility appears more important for both players, then $\mu>0.5$ (a principle of utilitarianism). Otherwise, if it is more important that the payoffs be close to each other, without great differences between them, then setting $\mu<0.5$ is appropriate (a principle of egalitarianism). An inappropriate magnitude of $\mu$ can cause a wrong results because minimum index (18) can change as $\mu$ changes (see an example of such a change in Figure 3 ).

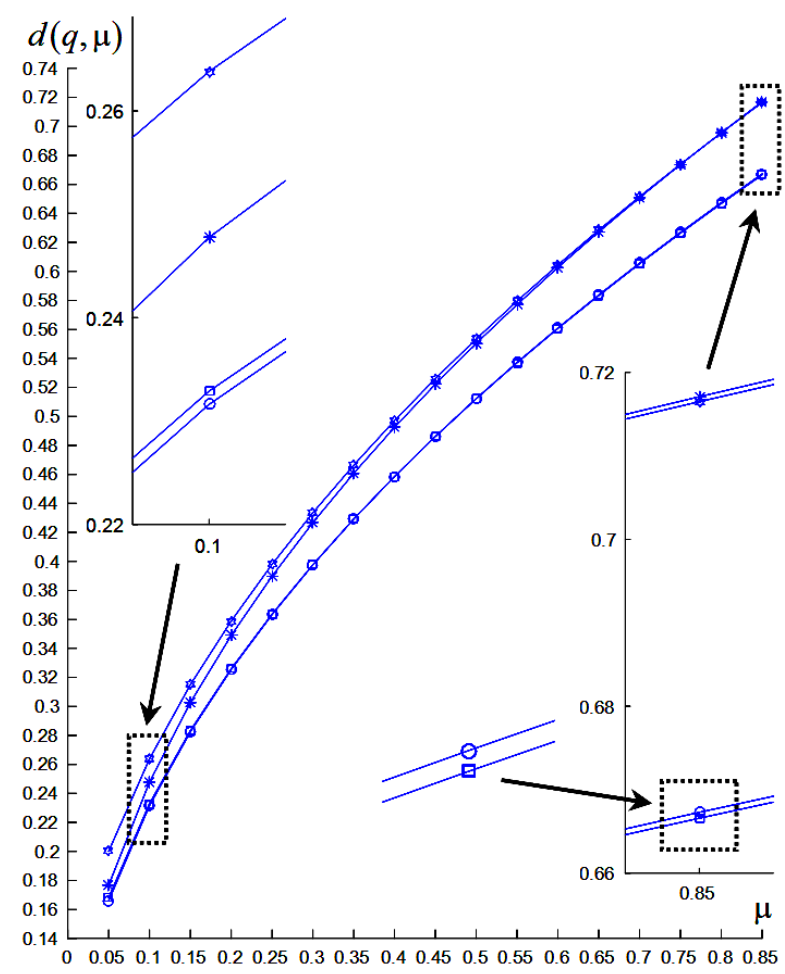

Figure 3 - Setting $\mu$ for the example of the $7 \times 6$ BMG with 4 ENEa mentioned in Figure 1, wherein the index $q_{*}$ of the SRNE (the best/refined ENEa), at which the shortest distance is reached, unexpectedly changes (from the circled point to the squared one)

If we are uncertain about greater importance of either the collective utility or the minimum payoff parity loss, then $\mu=0.5$ is the most appropriate choice. Nevertheless, if distance (17) is too sensitive to changes in $\mu$ in a vicinity of that half, then a justification for choosing $\mu=0.5$ is required. This is because, say, by $\mu=0.45$ we may have one solution (18), and by $\mu=0.55$ we may have a different solution (18). The same concerns any magnitude of $\mu$ at whose vicinity solution (18) changes.

Ranking of ENEa. With distance (17), ENEa are easily ranked. The first rank is at the best/refined ENE corresponded to the minimum of (17). The last rank is at the worst ENE, giving the players unsatisfactory collective utility and "tearing" the payoff parity severest, corresponded to the maximum of (17).

It is the easiest in $2 \times 2 \mathrm{BMGs}$ like those ones with PMs (5), (6), (7). Let $\mu=0.5$ just for these examples. 
Then in BMG with PMs (5) $d(1,0.5)=\sqrt{0.125} \approx 0.3536, d(2,0.5)=\sqrt{17 / 128} \approx 0.3644$, whence the ENE $z_{1}=\left\{x_{1}, y_{2}\right\}$ with the respective payoffs $\{4,4\}$ becomes the refined. As a generalization of such a BMG, in BMG with PMs (6) distance $d(1,0.5)$ remains the same, and

$$
d(2,0.5)=\sqrt{0.125+\delta^{2} / 8 \alpha^{2}}>d(1,0.5),
$$

i. e. the situation with ultimate parity is always the best.

Another examples are BMGs of bigger sizes: for

$$
\begin{aligned}
\mathbf{A} & =\left(\begin{array}{cccccccc}
2 & 32 & 37 & 14 & 26 & 19 & 42 & 15 \\
26 & 2 & 29 & 34 & 3 & 10 & 15 & 8 \\
36 & 16 & 0 & 42 & 36 & 44 & 17 & 1 \\
42 & 6 & 1 & 42 & 49 & 13 & 4 & 6 \\
29 & 36 & 26 & 14 & 2 & 41 & 34 & 47
\end{array}\right), \\
\mathbf{B} & =\left(\begin{array}{cccccccc}
9 & 20 & 33 & 43 & 30 & 31 & 47 & 36 \\
5 & 1 & 8 & 29 & 10 & 12 & 12 & 8 \\
38 & 0 & 15 & 23 & 31 & 40 & 35 & 23 \\
20 & 11 & 21 & 26 & 30 & 15 & 1 & 3 \\
26 & 49 & 27 & 28 & 25 & 33 & 4 & 18
\end{array}\right),
\end{aligned}
$$

having four ENEa $z_{1}=\left\{x_{1}, y_{7}\right\}, z_{2}=\left\{x_{3}, y_{6}\right\}, z_{3}=\left\{x_{4}, y_{5}\right\}$, $z_{4}=\left\{x_{5}, y_{2}\right\}$, all distances (17)

$$
\begin{gathered}
d(1,0.5) \approx 0.5205, d(2,0.5) \approx 0.5309, \\
d(3,0.5) \approx 0.5428, d(4,0.5) \approx 0.5295, \\
d(1,0.5)<d(4,0.5)<d(2,0.5)<d(3,0.5)
\end{gathered}
$$

allow ranking those ENEa without any troubles. ENE $z_{1}=\left\{x_{1}, y_{7}\right\}$ with its payoffs $\{42,47\}$ becomes the refined one. It is followed by $z_{4}=\left\{x_{5}, y_{2}\right\}$ with its payoffs $\{36,49\}$. A worse but not the worst is ENE $z_{2}=\left\{x_{3}, y_{6}\right\}$ with its payoffs $\{44,40\}$. The worst ENE here is $z_{3}=\left\{x_{4}, y_{5}\right\}$ whose payoffs $\{49,30\}$ have the greatest parity loss and produce the smallest collective utility.

Although ENE $z_{2}=\left\{x_{3}, y_{6}\right\}$ appears to have lost to ENE $z_{4}=\left\{x_{5}, y_{2}\right\}$ in this $5 \times 8$ BMG, a ratio

$$
d(2,0.5) / d(4,0.5) \approx 1.0028
$$

prompts that the difference between these ENEa is very small. The collective utility by the winner is 85 against that 84 of the loser, whereas the winner's payoff parity loss is 13 against that 4 of the loser. This means that increasing the weight of the payoff parity loss (by decreasing the weight of the collective utility) may make the losing ENE a winner (at least, against that ENE with the greater payoff parity loss and too small advantage by that 85 ). Indeed, setting $\mu=0.2$ gives distances

$$
\begin{aligned}
& d(1,0.2) \approx 0.3294, d(2,0.2) \approx 0.3359, \\
& d(3,0.2) \approx 0.3461, d(4,0.2) \approx 0.3362,
\end{aligned}
$$

that change ranks of those two neighboring ENEa. Moreover, setting $\mu \leqslant 0.0035$ changes the best ENE to $z_{2}=\left\{x_{3}, y_{6}\right\}$ with its minimum payoff parity loss.

$$
\begin{aligned}
& \text { A } 4 \times 7 \text { BMG whose PMs are } \\
& \mathbf{A}=\left(\begin{array}{lllllll}
6 & 6 & 7 & 7 & 3 & 6 & 5 \\
3 & 1 & 9 & 1 & 9 & 8 & 6 \\
4 & 4 & 6 & 9 & 2 & 0 & 4 \\
6 & 6 & 6 & 1 & 0 & 3 & 8
\end{array}\right), \quad \mathbf{B}=\left(\begin{array}{lllllll}
9 & 9 & 5 & 7 & 2 & 6 & 8 \\
7 & 5 & 7 & 4 & 5 & 8 & 1 \\
1 & 2 & 4 & 7 & 6 & 0 & 6 \\
9 & 4 & 2 & 1 & 7 & 5 & 4
\end{array}\right),
\end{aligned}
$$

has five ENEa: $z_{1}=\left\{x_{1}, y_{1}\right\}, z_{2}=\left\{x_{1}, y_{2}\right\}, z_{3}=\left\{x_{2}, y_{6}\right\}$, $z_{4}=\left\{x_{3}, y_{4}\right\}, z_{5}=\left\{x_{4}, y_{1}\right\}$. However, distances (17)

$$
\begin{aligned}
& d(1,0.5)=d(2,0.5)=d(5,0.5) \approx 0.57, \\
& d(3,0.5) \approx 0.5602, d(4,0.5) \approx 0.5605
\end{aligned}
$$

do not allow ranking those ENEa totally. The best ENE (which actually is SRNE) nonetheless exists - it is $z_{3}=\left\{x_{2}, y_{6}\right\}$ with the zero parity loss in its payoffs $\{8,8\}$. ENE $z_{4}=\left\{x_{3}, y_{4}\right\}$ is of the second rank losing very little with its payoffs $\{9,7\}$. Obviously, the rest three ENEa producing payoffs $\{6,9\}$ cannot be distinguished (there is no diversity in payoff pairs). Such a collision in BMGs may happen to a few best ENEa, whence an SRNE does not exist (in the sense of the suggested approach).

Relative ranking of ENEa. Distances (17) allow not only ranking ENEa from the best one down to the worst one. They also give ratios amongst the ENEa. Values $\{d(q, \mu)\}_{q=1}^{Q}$ are arranged as $\left\{d\left(q_{v}, \mu\right)\right\}_{v=1}^{Q}$, where

$$
d\left(q_{v}, \mu\right) \leqslant d\left(q_{v+1}, \mu\right) \text { by } v=\overline{1, Q-1}
$$

and

$$
d\left(q_{*}, \mu\right)=d\left(q_{1}, \mu\right) \text { by }\left\{q_{v}\right\}_{v=1}^{Q} \cap\{\overline{1, Q}\}=\{\overline{1, Q}\} .
$$

Then a value

$$
r\left(q_{v}, \mu\right)=d\left(q_{v+1}, \mu\right) / d\left(q_{v}, \mu\right)
$$

is a ratio showing an advantage of the $q_{v}$-th ENE over the $q_{v+1}$-th ENE by $v=\overline{1, Q-1}$. Ratios $\left\{r\left(q_{v}, \mu\right)\right\}_{v=1}^{Q-1}$ show relative ranking of ENEa that can be visualized as a histogram (Figure 4).

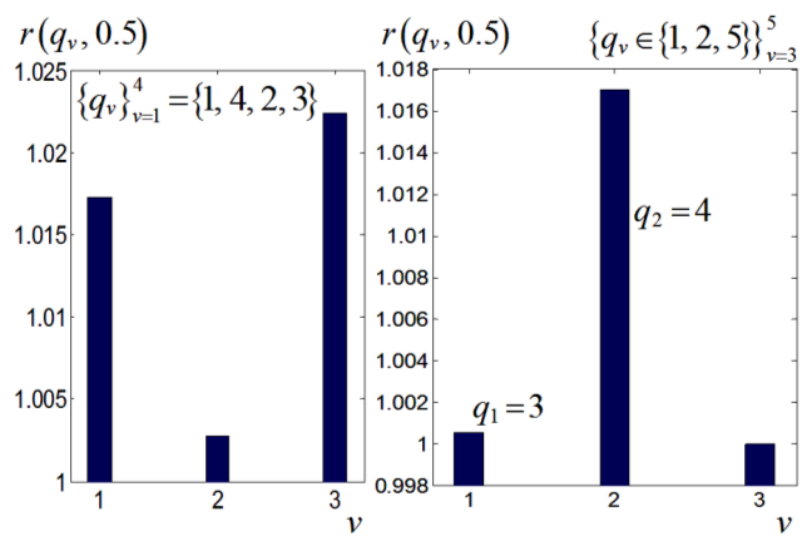

Figure 4 - Histogram bars showing relative ranking of ENEa by (21) in the exampled above $5 \times 8$ BMG (ranked totally) and $4 \times 7$ BMG (only the first two best ENEa are ranked due to no diversity in payoff pairs)

CONCLUSIONS. A couple of collective utility and minimum payoff parity loss rules is used as for refining $\mathrm{NEa}$, as well as for ranking ENEa in BMGs [18]. The best or (uniquely) refined ENE is $z_{q^{*}}=\left\{x_{q^{*}}^{*}, y_{q^{*}}^{*}\right\}$ by index (18). Although index (18) depends on how the weight $\mu$ is chosen for distance (17), an ultimate uncertainty case can be resolved by setting $\mu=0.5$ or about that. Cases $\mu<0.05$ and $\mu>0.95$, where the collective utility matters correspondingly so little and it matters so much, are unlikely in practice. 
Driven by the principle of the default collaboration, the best/refined ENE $z_{q^{*}}=\left\{x_{q^{*}}^{*}, y_{q^{*}}^{*}\right\}$ is the metaequilibrium preventing the players from springing off ENEa themselves. Its applications are basically in law, economics, bioecological processes, etc., where interaction events need the equilibria. A further research focuses on greater numbers of players.

\section{REFERENCES}

1. Nisan, N., Roughgarden, T., Tardos, É., Vazirani, V.V. (2007), Algorithmic Game Theory, Cambridge University Press, Cambridge, UK.

2. Osborne, M.J. (2003), An introduction to game theory, Oxford University Press, Inc., Oxford, UK.

3. Harsanyi, J.C., Selten, R. (1988), A General Theory of Equilibrium Selection in Games, The MIT Press, Cambridge, MA.

4. Myerson, R.B. (1978), "Refinements of the Nash equilibrium concept", International Journal of Game Theory, vol. 7, iss. 2, pp. 73-80.

5. Suh, S.-C. (2001), "An algorithm for verifying double implementability in Nash and strong Nash equilibria”, Mathematical Social Sciences, vol. 41, iss. 1, pp. 103-110.

6. Tian, G. (2000), "Implementation of balanced linear cost share equilibrium solution in Nash and strong Nash equilibria", Journal of Public Economics, vol. 76, iss. 2, pp. 239-261.

7. Kohlberg, E., Mertens, J.-F. (1986), "On the Strategic Stability of Equilibria”, Econometrica, vol. 54, no. 5, pp. 1003-1037.

8. Selten, R. (1975), "Reexamination of the perfectness concept for equilibrium points in extensive games", International Journal of Game Theory, vol. 4, iss. 1, pp. 25-55.

9. Myerson, R.B. (1978), "Refinements of the Nash equilibrium concept", International Journal of Game Theory, vol. 7, iss. 2, pp. 73-80.
10. Van Damme, E. (1984), “A relation between perfect equilibria in extensive form games and proper equilibria in normal form games", International Journal of Game Theory, vol. 13, iss. 1, pp. 1-13.

11. Fudenberg, D., Tirole, J. (1991), "Perfect Bayesian equilibrium and sequential equilibrium", Journal of Economic Theory, vol. 53, iss. 2, pp. 236-260.

12. Gerardi, D., Myerson, R. B. (2007), "Sequential equilibria in Bayesian games with communication", Games and Economic Behavior, vol. 60, iss. 1, pp. 104-134.

13. Mertens, J.-F. (1995), "Two examples of strategic equilibrium", Games and Economic Behavior, vol. 8, iss. 2, pp. 378-388.

14. Bajoori, E., Flesch, J., Vermeulen, D. (2013), "Perfect equilibrium in games with compact action spaces", Games and Economic Behavior, vol. 82, pp. 490-502.

15. Romanuke, V.V. (2016), "Sampling individually fundamental simplexes as sets of players' mixed strategies in finite noncooperative game for applicable approximate Nash equilibrium situations with possible concessions", Journal of Information and Organizational Sciences, vol. 40, no. 1, pp. 105-143.

16. Romanuke, V.V. (2010), "Recommendations on transacting the finite noncooperative game with invisible horizon of plays by NE-strategy", Science and Economics, iss. 2 (18), pp. 255-262.

17. Arias-Nicolás, J.P., Martín, J., Ruggeri, F., Suárez-Llorens, A. (2009), "Optimal actions in problems with convex loss functions", International Journal of Approximate Reasoning, vol. 50, iss. 2, pp. 303-314.

18. Hinojosa, M.A., Lozano, S., Borrero, D.V., Mármol, A.M. (2017), Ranking efficient DMUs using cooperative game theory, Expert Systems with Applications, vol. 80, pp. 273-283.

\section{ПАРА ПРАВИЛ КОЛЛЕКТИВНОЙ ПОЛЕЗНОСТИ И МИНИМАЛЬНЫХ ПОТЕРЬ ПАРИТЕТА ВЫИГРЫШЕЙ ДЛЯ ОТБОРА РАВНОВЕСИЙ НЭША В БИМАТРИЧНЫХ ИГРАХ С АСИММЕТРИЧНЫМИ ВЫИГРЫШАМИ}

\section{В. В. Романюк}

Военно-морская Академия Польши

ул. Шмидовича, 69, г. Гдыня, Польша, 81-127. E-mail: romanukevadimv@ gmail.com

Для усовершенствования известных подходов к отбору равновесий Нэша должен быть предложен подход, который бы мог использовать больше, чем просто одну методику оперирования над выигрышами в биматричных играх. Для создания такого нового подхода должны быть сформулированы начальные обозначения, конвенция по матрицам выигрышей, конвенция о рационализме игроков и математическая задача отбора. Предполагается, что игроки не является чисто жадными, то есть некоторые уступки/отступления допустимы. Игроки могут потерять без отступлений больше, но отступление должно быть осуществлено одним игроком. Происходит фокусировка на эффективное равновесие Нэша, которое соответствует минимальному отступлению и называется метаравновесием. Изложено двухкритериальную задачу для метаравновесия, в которой коллективная полезность максимизируется, а потеря паритета выигрышей - минимизируется. Эта задача решается путем скаляризации со взвешиванием критериев. Пара правил коллективной полезности и минимальных потерь паритета выигрышей используется как для отбора равновесий Нэша, так и для ранжирования эффективных равновесий Нэша. Метаравновесие не позволяет игрокам спрыгивать с самих равновесий. Его применение в основном касается права, экономики, биоэкологических процессов.

Ключевые слова: равновесия Нэша, отбор, биматричные игры, коллективная полезность, потеря паритета выигрышей, метаравновесие.

Стаття надійшла 19.01.2018. 